\title{
MASUK DAN BERKEMBANGNYA GERAKAN TARBIYAH, STUDI KASUS: GERAKAN DAKWAH KAMPUS DI INSTITUT TEKNOLOGI BANDUNG (ITB) 1983-1998
}

\author{
Arditya Prayogi \\ Arkom Political Research (CV.SBI) \\ Alamat korespondensi: Arditya.prayogi@yahoo.com \\ Diterima: 31 Desember 2018; Direvisi: 23 Januari 2019; Disetujui: 25 Januari 2019
}

\begin{abstract}
This research paper discusses the dynamics of the Tarbiyah Movement with a case study of campus da'wah movements at ITB in the era 1983 to 1998, emphasizing that the development of campus-based da'wah nationally can be said to start from the ITB campus. The research in this paper uses a historical method which consists of 4 stages, namely heuristics, criticism, interpretation, and historiography. This research discusses the emergence and development of the tarbiyah da'wah movement which was influenced by the thoughts of the Muslim Brotherhood (Ikhwan). The Tarbiyah movement grew and developed from the campus missionary movement which was originally conceived by DDII through the Bina Masjid Kampus which was further developed by tarbiyah cadres through various programs. The entry of tarbiyah thought in ITB was transformed institutionally into the GAMAIS as internal organ in ITB and KAMMI as external organ outside ITB.
\end{abstract}

Keywords: Movement of Tarbiyah, Brotherhood, Da'wah, Gamais, Kammi

Abstrak

Penelitian ini membahas tentang dinamika Gerakan Tarbiyah dengan studi kasus gerakan dakwah kampus di ITB pada era 1983 hingga 1998, dengan menekankan bahwa perkembangan dakwah berbasis kampus secara nasional dapat dikatakan dimulai dari kampus ITB. Penelitian dalam paper ini menggunakan metode sejarah yang terdiri dari 4 tahap yaitu heuristik, kritik, intepretasi, dan historiografi. Penelitian ini membahas muncul dan berkembangnya gerakan dakwah tarbiyah yang terpengaruh pemikiran Ikhwanul Muslimin. Gerakan Tarbiyah tumbuh dan berkembang dari gerakan dakwah kampus yang awalnya digagas oleh DDII melalui Bina Masjid Kampus yang kemudian dikembangkan lebih lanjut oleh kader-kader tarbiyah melalui berbagai program. Masuknya pemikiran tarbiyah di ITB ditransformasikan menjadi Lembaga Dakwah Kampus GAMAIS secara kelembagaan internal di ITB dan KAMMI secara eksternal di luar ITB.

Kata Kunci: Gerakan Tarbiyah, Ikhwan, Dakwah, Gamais, Kammi

\section{A. Pendahuluan}

Peristiwa

Reformasi

1998 merupakan fenomena dimana mahasiswa dengan beragam latar belakang tumpah ruah dan menjadi satu dengan tuntutan "Reformasi". Dalam momentum reformasi ini terdapat beragam unsur mahasiswa yang terlibat, termasuk didalamnya mahasiswa Islam (muslim) dengan berbagai corak gerakan dan kendaraan organisasi. Namun demikian, pihak yang menjadi katalisator utama dari munculnya pergerakan mahasiswa Islam di
Indonesia adalah Dewan Dakwah Islamiyah Indonesia (DDII). DDII terus memotori pergerakan mahasiswa Islam di Indonesia hingga memunculkan berbagai pergerakan lain di belakangnya. Pun begitu, pada awal tahun 1980-an, (sebelum bergulir Reformasi), mahasiswa menemukan pola baru untuk menampung idealisme dan mewadahi aktivitasnya. Setidaknya ada lima bentuk aktivitas baru mahasiswa yang berkembang sepanjang era 80-an, yaitu: 
1) Kelompok-kelompok Studi Kritis, yang umumnya mengacu pada kepustakaan Barat,

2) Penerbitan Mahasiswa,

3) LSM (Lembaga Swadaya Masyarakat),

4) Komite-komite Aksi, dan

5) Aktivitas Ke-Islaman berbasis Masjid Kampus (Sidiq, 2003: 59).

Dari lima bentuk aktivitas baru mahasiswa yang berkembang ini, selanjutnya, kelompok mahasiswa dengan tipikal aktivitas yang kelima ini menjadi bahasan dalam paper ini. Gerakan Dakwah Kampus -begitu bentuk aktivitas baru mahasiswa ini disebut, menjadi penting dalam melancarkan ide-ide perubahan dan kebangkitan di Indonesia di tengah stagnasi dan pengekangan yang telah berlangsung paling tidak selama tiga dasawarsa sebelumnya. Ide perubahan dengan mengusung Islam sebagai ide dasar juga dianggap dapat mendorong serta menarik simpati masyarakat Indonesia -yang mayoritas Islam untuk turut bergerak mejadi agent of change. Hal ini penting dalam konteks perubahan dan kebangkitan di Indonesia mengingat semangat keIslam-an dan ke-Indonesia-an dalam rentang panjang sejarah Indonesia justru menjadi semangat yang saling melengkapi satu sama lain. Di luar alas an subtantif ini, gerakan dakwah kampus menjadi penting dalam memberikan gambaran posisi Islam dalam kehidupan civitas academica di Indonesia.

Para mahasiswa (aktivis) yang berkecimpung dalam pola kelima ini sering dikenal dengan aktivis dakwah kampus (ADK). Aktivitas ini pada mulanya dimotori oleh DDII (Dewan Da'wah Islam Indonesia), berusaha untuk menyatukan pemikiranpemikiran tradisionalis dan modernis dalam tataran praktis dengan memasuki wilayah kampus sebagai ranah yang cukup menjanjikan bagi perkembangan da'wah Islam, hingga muncullah sebuah gerakan yang benar-benar baru dalam sejarah panjang gerakan (berbasis) Islam di Indonesia (Machmudi, 2005: 16). Menjelang pertengahan 1980, aktivitas dakwah kampus mengalami sentuhan langsung dengan gerakan-gerakan Islam yang bercorak Internasional/Transnasional. ${ }^{1}$ Gerakan ini kemudian mewarnai aktivitas mahasiswa muslim di ITB melalui Majelis Ta'lim (Mata) Salman. Karena konsentrasinya yang mendalam terhadap tarbiyah Islamiyyah (pendidikan/pembinaan ke-Islaman) hingga terbitnya buku Panduan Tarbiyah dan Kurikulum Materi Tarbiyah sebagai pedoman di setiap usrah-nya, akhirnya Gerakan ini dikenal dengan nama Gerakan Tarbiyah. ${ }^{2}$ Paper ini mencoba mendeskripsikan Gerakan Tarbiyah yang masuk dan berkembang di

Istilah transnasional secara jelas digunakan Hasyim Muzadi, mantan Ketua Pengurus Besar Nahdlatul Ulama (PB NU), sebagai suatu ungkapan kekhawatiran terhadap perkembangan Gerakan Islam Baru di Indonesia. Hasyim mengatakan bahwa gerakan Islam transnasional merupakan sesuatu yang akan menghancurkan NKRI. Ia menghimbau warga NU agar waspada terhadap ideologi transnasional. Organisasi transnasional yang disebut oleh Hasyim, yaitu Ikhwanul Muslimin (IM), Hizbut Tahrir (HT) dan Majelis Mujahiddin Indonesia (MMI). Lebih lanjut Hasyim menyebutkan bahwa ketiga gerakan tersebut merupakan sebuah gerakan politik, bukan gerakan keagamaan.9 Gerakan tersebut muncul dari situasi politik di negeri asalnya. Penyebutan ketiga nama ini dilanjutkan dengan seruan kepada pemerintah agar bertindak tegas terhadap ketiga organisasi tersebut. (NU Online. Senin, 9 Juli 2007).

2 Bahwa gerakan tarbiyah yang dimaksud disini merupakan bagian dari gerakan Ikhwanul Muslimin (IM), sering menyebut sebagai ikhwan- di Mesir merupakan gerakan transnasional yang mendasarkan gagasannya pada gagasan tandzhim 'alamy (struktutal pusat tingkat dunia) di Mesir. Penegasan bahwa gerakan tarbiyah merupakan bagian yang tidak terpisahkan dari Ikhwan di Mesir adalah kata-kata Dr. Yusuf Al Qaradhawi, salah satu ulama besar Ikhwan yang pernah berkata bahwa Tarbiyah di Indonesia merupakan kepanjangan tangan Ikhwan di Mesir. Gerakan transnasional sendiri memiliki ciri, bersifat transnasional, ideologi gerakan tidak lagi bertumpu pada konsep nationstate, melainkan konsep umat, didominasi oleh corak pemikiran skripturalis, fundamentalisme atau radikal, dan secara parsial mengadaptasi gagasan dan instrumen modern. Sebelumnya, persentuhan pemikiran dari gerakan-gerakan Transnasional/Internasional hanya melalui bukubuku yang diterjemahkan oleh Bang Imad (Dr. Ir. Imaduddin Abdul Rahim, M.Sc) ataupun buku-buku yang tersimpan di dalam perpustakaan milik DDII. (Machmudi, 2005: 17). 
kampus ITB, mengingat ITB merupakan titik awal bagi perkembangan gerakan dakwah kampus secara nasional yang menjadi "pusat" dakwah nasional gerakan tarbiyah di berbagai kampus di Indonesia yang sejak permulaannya dimotori oleh DDII pada 1970-an.

\section{B. Metode Penelitian}

Metode penelitian yang digunakan dalam paper ini adalah metode penelitian sejarah yang terdiri atas empat tahapan yang meliputi heuristik, kritik, interpretasi, dan historiografi. Tahap heuristik merupakan proses mencari, menelusuri, serta menemukan sumber yang berhubungan dengan tema penelitian sebanyak-banyaknya. Dalam hal ini, heuristik dilakukan dengan 2 cara yaitu model studi pustaka dengan jalan mencari sebanyak mungkin sumber-sumber literatur baik primer maupun sekunder serta dengan melakukan wawancara yang dianggap memiliki kompetensi terhadap tema penelitian. Studi pustaka yang dilakukan dalam penelitian ini dilakukan dengan menelusuri tempattempat yang peneliti anggap menyimpan sumber-sumber pustaka. Adapun tempat-tempat yang dijadikan pencarian sumber di antaranya:

1. Perpustakaan Fakultas Ilmu Budaya Universitas Padjajaran, Jatinangor.

2. Perpustakaan Cisral Universitas Padjadjaran, Bandung.

3. Perpustakaan Daerah Provinsi Jawa Barat yang bertempat di Bandung.

Sedangkan penelusuran sumber berupa wawancara dilakukan dengan melakukan wawancara semi-terstruktur. Wawancara semiterstruktur digunakan untuk menemukan permasalahan secara lebih terbuka, yang diajak wawancara diminta pendapat, dan ide-idenya.
Wawancara dilakukan dengan memilih objek wawancara yang penulis anggap memiliki kompetensi terhadap informasi yang dibutuhkan oleh peneliti dalam penelitian ini.

Selanjutnya sumber yang telah terkumpul tersebut diseleksi melalui tahap yang kedua yaitu tahap kritik. Dalam tahap ini sumber-sumber yang terkumpul diuji untuk mendapatkan sumber yang akurat. Kritik dilakukan secara ekstern dan intern. Kritik ekstern bertujuan menguji keotentikan suatu sumber termasuk menyelidiki bentuk sumber, usia, waktu, serta segala hal yang terkait dengan asli atau tidaknya sumber itu. Sementara kritik intern bertujuan menguji dengan kritis dan akurat mengenai isi sumber, apakah dapat dipercaya kebenarannya atau tidak. Kritik intern berusaha membuktikan adanya kesaksian atau informasi yang diberikan oleh sumbersumber itu yang dapat dipertanggungjawabkan dan dipercaya. Adapun cara membuktikannya dengan penilaian intrinsik, yaitu penilaian terhadap sifat dari sumber-sumber itu dan meneliti pengarang sumber itu sendiri serta kapasitas, kapabilitas, dan kemauan sumber. Melalui kritik ekstern dan intern peneliti dapat memastikan bahwa sumber-sumber yang digunakan telah sesuai dengan kebutuhan terhadap penelitian ini.

Tahap ketiga yaitu tahap interpretasi. Tahapan ini merupakan tafsiran kita atas data yang terkumpul sehingga menghasilkan sebuah uraian. Tafsiran dilakukan dengan seobjektif mungkin, sesuai dengan data dan fakta yang ada, walaupun sisi-sisi subjektivitas pasti akan tetap ada. Intepretasi dalam penelitian ini dilakukan dengan menggunakan deskripsi dan didukung dengan pendekatan ilmu-ilmu bantu dalam 
sejarah, terutama melalui deskripsi dan kerangka teoritis politik Islam Transnasional. Selanjutnya, setelah datadata tersebut diinterpretasi, maka disusunlah historiografi yang merupakan tahapan terakhir dalam metode penelitian sejarah untuk memaparkan dan menerangkan hasil interpretasi menjadi suatu narasi rekonstruksi sejarah yang dituangkan dalam bentuk jurnal penelitian berjudul Masuk dan Berkembangnya Gerakan Tarbiyah, Studi Kasus: Gerakan Dakwah Kampus di Institut Tehnologi Bandung (ITB) 1983-1998.

\section{C.Pembahasan}

\section{Gerakan Dakwah Kampus Pra Masuknya Gerakan Tarbiyah; Gerakan Dewan Dakwah Islam Indonesia (DDII) sebagai Perintis}

Pada tahun 1974, DDII (Dewan Dakwah Islam Indonesia) mengawali usaha untuk masuk ke dalam dunia kampus dengan lebih sistemik. Karena pada dasarnya, kegiatan berbasis kampus DDII sudah dimulai sejak tahun $1968 .^{3}$

Natsir sebagai motor penggerak DDII mengumpulkan 40 orang yang direkrut dengan cara melakukan koordinasi dengan lembaga atau organisasi tempat mereka bernaung, seperti HMI (Himpunan Mahasiswa

${ }^{3}$ Dewan Dakwah Islamiyah Indonesia (DDII) didirikan pada 26 Februari 1967. Lembaga ini lahir dari sebuah musyawarah yang dilakukan oleh beberapa tokoh ulama di Jakarta pada pertemuan halal bihalal pada 1967. Pada pertemuan ini dibahas tentang perkembangan dakwah di Indonesia pada saat itu, terutama masa transisi politik setelah terjadinya pemberontakan G 30 S/ PKI 1965. Forum dihadiri oleh Mohammad Natsir, H.M. Rasyidi, K.H. Taufiqurrahman, H. Mansyur Daud Datuk Palimo Kayo dan H.Nawawi Duski. Menurut mereka, perkembangan dakwah Islam cukup memprihatinkan. Dakwah Islam yang dilakukan, baik perorangan maupun lembaga keagamaan, dinilai berjalan sporadis, kurang kordinasi dan terlalu konvensional. Melihat kenyataan tersebut, mereka akhirnya mendirikan lembaga yang berbentuk yayasan yang bertujuan untuk menggiatkan dan meningkatkan mutu dakwah Islam di Indonesia. (Luth, 1999: 56).
Islam), PII (Pelajar Islam Indonesia), atau Muhammadiyah. Empat puluh orang tersebut berasal dari kampus ITB, Unpad, dan IKIP Bandung. Adapun koordinator panitia (Project Officer) yang ditunjuk oleh M. Natsir pada pelatihan pertama ini adalah K.H. Z.E. Muttaqien yang biasa disebut Kang Engkin. Beliau adalah dosen agama Islam di ITB dan merupakan salah satu pentolan Masyumi di Bandung. Sedangkan yang bertindak menjadi asisten utama PO pada saat itu adalah Bang Imad. Para peserta digembleng selama tiga hari di gedung PHI (Panitia Haji Indonesia) Kwitang di Jakarta. Mereka di upgrade oleh para tokoh seperti M. Natsir, Dr. Rasyidi, Osman Raliby, Zainal Abidin Ahmad, dan beberapa tokoh lainnya. Selesai acara, para peserta kemudian diberi tugas untuk kembali ke kampus masing-masing dengan menjadi dosen atau asisten dosen mata kuliah agama Islam. Alumni angkatan pertama PHI itu juga membentuk komunitas rutin yang mengadakan pertemuan setiap bulan (Asshidiqie, 2002: 160-163).

Sebagai gerakan pengkaderan, khususnya mencetak instruktur aktivis dakwah di lingkungan kampus, PHI selalu membangun lingkaran dan forum silaturahim setelah selesai mengikuti upgrading pembinaan keislaman. Komunitas ini kemudian menggarap dakwah di masjid-masjid kampus, dengan DDII sebagai pelindungnya. Setelah Proses pengkaderan ini berakhir, para alumni tersebut kemudian melanjutkan penyelenggaraan training di kampus. ${ }^{4}$

4 Sebagai sebuah gerakan yang berbasis masyarakat umum (bukan mahasiswa), perlu dicatat keberhasilan DDII dalam menghidupkan aktivitas da'wah di kampus-kampus di Indonesia. DDII kerap kali melakukan daurah (pelatihan ke-Islaman) di berbagai universitas, khususnya para mahasiswa yang akan menjadi dosen di universitas-universitas negeri. Namun aktivitas DDII belum mampu menyentuh tataran internal mahasiswa karena kegiatannya, walaupun diadakan untuk mahasiswa lebih bersifat eksternal dan terkesan eksklusif. Dapat baca, Matta, Anis. 2006. Dari Gerakan Ke Negara; Sebuah Rekonstruksi 
Gerakan berbasis masjid kampus yang bersifat internal sendiri baru dirintis di ITB (Institut Teknologi Bandung). Para pionir dari gerakan ini adalah Ir. TM. Sulaiman, Prof. Drs. Ahmad Sadali, dan Ir. Nukman. Mereka pulalah yang mendesak rektor ITB untuk membangun sebuah masjid di kampus dan untuk pertama kalinya berdirilah sebuah masjid di lingkungan kampus ITB yang kemudian dikenal dengan nama Masjid Salman Al Farisi -yang juga menjadi inspirator bagi berdirinya masjid-masjid kampus di beberapa universitas negeri di Indonesia. Menyusul berdirinya Masjid Al Ghifari di IPB (Institut Pertanian Bogor), Masjid Al Furqan di UPI (Universitas Pendidikan Indonesia -dulu IKIP Bandung), dan beberapa masjid lainnya.

Keberadaan masjid kampus (atau masjid di sekitar kampus) benar-benar menjadi sentral dan basis perjuangan mahasiswa Muslim di kampus, khususnya keberadaan masjid Salman Al Farisi di lingkungan kampus ITB. Dari sinilah kemudian terjadi sinergitas antara aktivitas internal kampus --yang berbasis di masjid-masjid kampus-- dan aktivitas eksternal kampus yang pada awalnya dimotori oleh DDII.

Pada tahun 1974, DDII kemudian berinisiatif untuk memfasilitasi para mahasiswa yang telah bergabung dalam aktivitas masjid kampus dengan membentuk BMKI (Bina Masjid Kampus Indonesia) yang bertujuan untuk mengorganisir kekuatan para aktivis masjid kampus se-Indonesia sekaligus menyebarkan dakwah di masjid-masjid kampus di seluruh Indonesia. Dengan ditangani langsung oleh mahasiswa, aktivitas BMKI menjadi terasa begitu nyata dan memberikan manfaat secara

Negara Madinah yang Dibangun dari Bahan Dasar Sebuah Gerakan. Jakarta: Fitrah Rabbani. langsung bagi mahasiswa karena pengelola begitu tahu apa yang memang benar-benar dibutuhkan oleh mahasiswa dalam berdakwah. Dikelolanya BMKI oleh mahasiswa mungkin juga dilakukan DDII karena sebagian besar aktivis DDII tidak begitu memahami secara langsung aktivitas kampus. Jadi, DDII menyerahkan hasil dari proyeknya langsung pada mahasiswa untuk mengelolanya. BMKI kemudian menunjuk koordinator di setiap wilayah untuk mengembangkan dakwahnya di masing-masing kampus. Tercatat nama-nama Amin Rais, Kuntowijoyo dan M. Mahyuddin sebagai koordintaor daerah Yoyakarta; Ahmad Sadali, Rudy Syarif Sumadilaga, Yusuf Amir Feisal (Bandung); M. Daud Ali dan Nurhay Abdurahman (Jakarta); Halidzi dan Abdurahman Basalama (Ujung Pandang); Kafiz Anwar (Semarang); dan A.M. Saefudin dan Abdul Kadir Jaelani (Bogor). Memasuki akhir 1970-an, aktivitas dakwah yang menjadikan masjid kampus sebagai basis utama bagi gerakannya semakin mendapat dukungan dari mahasiswa. Bahkan, gerakan dakwah berbasis masjid kampus telah menjadi alternatif "baru" dalam menyalurkan aktivitas mahasiswa di luar kuliah (Asshidiqie, 2002: 162).

\section{Awal Mula Gerakan Tarbiyah di Kampus ITB}

Seperti yang telah disinggung sebelumnya, gerakan tarbiyah yang muncul merupakan sebuah konsekuensi yang muncul dari persinggungan ideide organisasi (Islam) internasional/transnasional di Indonesia. Termasuk gerakan tarbiyah, ${ }^{5}$

5 Pada awal 1980, umat Islam di Indonesia dibanjiri oleh -setidaknya- empat arus besar pemikiran Islam transnasional. Keempat pemikiran tersebut adalah $\mathrm{Al}$ Ikhwan Al Muslimun (Ikhwan), Hizb at Tahrir (HT), Salafy, dan Jama'ah Tabligh (JT). Dalam praktiknya, keempat arus tersebut kemudian terfragmentasi kembali menjadi gerakan 
yang masuk ke Indonesia, terutama di kampus ITB, mengalami dua fase perkembangan. Fase pertama berjalan dari tahun 1983-19906 dan fase kedua berjalan pada tahun 1990-1998.7

Di ITB sendiri, kegiatan pembinaan gerakan tarbiyah mulai masuk sekitar tahun 1985. Pada kurun waktu sebelum itu, gerakan tarbiyah mengadakan majelis ta'lim (Mata) di masjid Salman Al Farisi, namun pesertanya tidak terbatas pada kalangan mahasiswa saja. Begitu pun dengan penanggungjawab kegiatan tersebut. Pada masa-masa tersebut, tandzhim/pengurus internal kampus ITB belum terbentuk sehingga kegiatan-kegiatan gerakan tarbiyah langsung dipegang oleh tandzhim daerah (langsung atas kuasa pengurus

yang lebih spesifik lagi. Di sini kita hanya akan membahas Al Ikhwan Al Muslimun (Ikhwan), karena dari sanalah akar pemikiran Gerakan Tarbiyah di Indonesia. Terkait perkembangan dan peng-asosiasi-an gerakan tarbiyah dengan/dan Ikhwanul Muslimin dapat baca, AzhZhawahiri, Ayman. 2008. Dari Rahim Ikhwanul Muslimin ke Pangkuan Al-Qaida (terj). Klaten: Kafayeh. Terkait pola dan mekanisme keorganisasian dapat baca, Imdadun, Muhammad. 2003. Transmisi Gerakan Revivalisme Islam Timur Tengah ke Indonesia (1980-2002): Studi Atas Gerakan Tarbiyah dan HTI).Yogyakarta. Makalah Seminar FSLDK.

${ }^{6}$ Kalangan aktivis tarbiyah menyebut fase pertama ini sebagai fase ta'sis tandzhimi, yaitu fase dimana gerakan tarbiyah memulai membangun basis gerakannya. Pada fase ini, gerakan tarbiyah memfokuskan gerakannya pada pembinaan yang sangat intensif di kalangan anggotanya. Penanaman ideologi pada fase ini mendapat perhatian yang lebih besar daripada aktivitas lainnya. Kader tarbiyah pada fase ini cenderung menutup diri dari berbagai aktivitas di luar aktivitas pembinaan. Pergaulan, bacaan, dan interaksi para kader dengan dunia di luar ideologi mereka sangat dibatasi. Namun tidak untuk interaksi sosial. Para kader tetap diperbolehkan bergaul dengan kaidah membaur namun tidak melebur. Ciri ideologis yang kental dalam fase ini merupakan karakter aktivis dakwah kampus yang dibina tarbiyah. Aktivis gerakan tarbiyah di ITB juga mengikuti alur ini. Mereka kemudian mulai terjun langsung ke masyarakat, tidak hanya berkutat dengan aktivitasnya di GAMAIS, namun juga mengisi pengajian dan mengajar TPA di masjid-masjid sekitar tempat tinggalnya. Aktivitas ini dilakukan untuk mengubah paradigma masyarakat tentang gerakan dakwah atau gerakan islam secara umum yang semakin ternodai oleh tindakan-tindakan teror oknum sekaligus meraih dukungan masyarakat dari tindakan represif orde baru, terutama pasca tragedi Tanjung Priok, yang efeknya masih bisa dirasakan hingga awal tahun 1990an. Wawancara dengan salah satu kader Gerakan Tarbiyah Unpad, Rd Laili Al-Fadli, November 2009.

7 Fase kedua ini yang dikenal juga dengan nama fase sya'bi merupakan fase di mana gerakan tarbiyah sudah mulai terjun langsung ke masyarakat, baik masyarakat kampus maupun masyarakat umum di sekitar kampus. Dalam masa ini begitu banyak aktivitas-aktivtas sosial gerakan tarbiyah dengan menggunakan nama Yayasan yang didirikan oleh para aktivisnya. Wawancara dengan salah satu kader Gerakan Tarbiyah Unpad, Rd Laili Al-Fadli, November 2009.
Gerakan Tarbiyah tingkat Kota Bandung) 8

Untuk melakukan pembinaan yang intensif terhadap mahasiswa Islam di ITB, pengurus masjid Salman Al Farisi dilakukan dengan didirikannya Unit Pelayanan Mahasiswa (P2M) yang bekerjasama dengan unit Hari Besar Islam (HBI) dalam menjaring mahasiswa-mahasiswa baru ITB ke berbagai aktivitas kegiatan mahasiswa di Masjid Salman Al Farisi. Langkah selanjutnya dilakukan dengan aktivitasaktivitas non formal yang menuju pada penggalangan potensi mahasiswa yang terjaring dalam kegiatan HBI. Namun, karena kebutuhan mahasiswa semakin kompleks dengan segala macam persoalan di dalamnya, kedua langkah ini belum memecahkan persoalan terbengkalainya urusan-urusan kampus dalam kerangka Dakwah Salman. Hal ini yang mendorong didirikannya sebuah Lembaga Dakwah Kampus di ITB. 9

Pada tahun 1986, aktivis dakwah kampus angkatan 1986 secara non formal membentuk Keluarga Mahasiswa Muslim 1986 yang kemudian menjadi cikal bakal dari GAMAIS ITB. Kegiatan-kegiatan yang dilakukan masih sebatas pada pelaksanaan pengajian di tiap jurusan yang ada di ITB. Baru pada tanggal 27 Agustus 1987, Keluarga Mahasiswa Muslim 1986 berubah nama menjadi Keluarga Mahasiswa Islam (GAMAIS) ITB. Hal ini dilakukan untuk memperluas garapan dakwah. Sebagian mahasiswa yang berperan dalam pembentukkan lembaga tersebut adalah mereka yang telah rutin mengikuti Mata Salman.

${ }^{8}$ Wawancara dengan Sdr Burhan, aktivis tarbiyah di ITB, Desember 2009.

9 Lihat http://gamais.itb.ac.id/profil-gamais, diakses November 2009. 
Kehadiran GAMAIS ITB pada awalnya seperti menjadi kompetitor dari kegiatan-kegiatan yang diadakan secara struktural internal oleh Masjid Salman Al Farisi, seperti misalnya LMD (Latihan Mujahid Dakwah) . LMD sendiri menjadi semakin sepi peminat dan tidak lagi berjalan intensif karena sebagian besar mahasiswa lebih memilih untuk mengikuti kegitan Mata (Majelis Ta'lim) ITB yang saat itu dimotori (secara struktural) oleh gerakan tarbiyah. Namun demikian, melalui komunikasi dan koordinasi yang intens, akhirnya disepakati bahwa GAMAIS ITB yang kemudian fokus untuk menggarap mahasiswa ITB, sedangkan Masjid Salman Al Farisi beserta organisasi di bawahnya menggarap segmen yang berbeda. Misalnya, organ PAS yang menggarap anak-anak di sekitar Masjid Salman, kemudian KHARISMA ITB menggarap remaja, dan DKM Salman Al Farisi menggarap para orang tua, baik bapak-bapak maupun ibu-ibu di sekitar masjid Salman. Dalam perjalanannya, GAMAIS ITB kemudian menjadi basis gerakan tarbiyah. Tidak terdeteksi kapan tepatnya gerakan tarbiyah "mengambil alih" aktivitas GAMAIS ITB. Namun pola gerakan tarbiyah terlihat sangat kental mewarnai lembaga ini. Pola kaderisasi, sistem pembinaan, dan kegiatan-kegiatan yang diadakan oleh GAMAIS ITB sangat berwarna Tarbiyah/Ikhwan (IM). ${ }^{10}$

10 Pola gerak dakwa kampus yang dipakai oleh GAMAIS ITB mengikuti pola umum yang terdapat dalam konsep Gerakan Ikhwan dengan melalui tiga tahapan da'wah ${ }^{10}$ yaitu ta'rif (perkenalan), takwin (pembentukan), dan tanfidz (pelaksanaan). Ketiga tahapan tersebut merupakan bentuk yang juga termuat dalam Fighu Da'wah Ikhwanul Muslimin. Implementasi dari ketiga bentuk tersebut dilakukan oleh GAMAIS ITB yang secara umum telah menerima konsep ini sebagai konsep umum da'wah kampus. Pada fase ini, sikap para aktivis tarbiyah cenderung "radikal", yang ditunjukkan dengan cara "memusuhi" segala lambang Negara, walau tidak secara frontal. Wawancara dengan salah satu kader Gerakan Tarbiyah Unpad, Rd Laili Al-Fadli, November 2009.
Pola manajemen da'wah kampus yang dilakukan oleh Gerakan Tarbiyah ini memiliki perbedaan jika dibandingkan dengan model dakwah kampus era ormas kemahasiswaan (HMI, dan lainnya). Perbedaannya adalah kepada apa yang oleh kalangan Gerakan Tarbiyah disebut manhaj. Manhaj bisa berarti sistem atau pijakan. Manhaj dakwah kampus sudah mulai disusun dan diimplementasikan sejak awal 1990-an oleh Gerakan Tarbiyah. Selain itu, Gerakan Tarbiyah senantiasa mengangkat isu-isu internasional, seperti pembebasan Afghanistan yang saat itu diduduki tentara Uni Sovyet hingga dukungannya terhadap kemerdekaan Palestina. Beberapa kebiasaan para aktivis Gerakan Tarbiyah ini juga menandai adanya sebuah pembaharuan dalam budaya ummat Islam (khususnya kalangan mahasiswa) di Indonesia seperti penggunaan jilbab misalnya. Penggunaan jilbab yang lebih lebar di kalangan aktivis muslimah gerakan ini bila dibandingkan kebiasaan masyarakat Indonesia pada umumnya menjadi suatu fenomena menarik. Selain itu, kebiasaan para aktivisnya untuk membumbui percakapannya dengan kata-kata bahasa Arab seperti ana, antum, afwan, atau syukran juga menjadi sebuah fenomena lain yang juga menarik di kalangan aktivis ini.

Satu hal lagi yang perlu dicatat adalah pengaruh pembinaan usrah yang dilakukan Gerakan Tarbiyah adalah bahwa nantinya gerakan ini kemudian sanggup menyadarkan bahwa dengan menjadi mahasiswa berarti harus peduli terhadap kondisi bangsa dan Negara. Aktivitas da'wah kampus yang pada awalnya hanya terbatas pada aspek sosial keagamaan ini sanggup bertransformasi menjadi gerakan nyata yang sangat politis dengan ikut serta 
dalam pergulatan reformasi. Sebuah sikap politik yang tegas dalam menentukan arah gerakan mahasiswa muslim dalam menyikapi kondisi bangsa dan Negara pada tahun 1998. Gerakan ini juga menjadi sangat penting karena lebih dari itu, gerakan mahasiswa muslim merupakan gelombang yang sangat besar dan cukup berperan dalam mengangkat isu reformasi pada tahun 1998.

\section{Pengaruh Gerakan Tarbiyah terhadap Dakwah Kampus di ITB}

Gerakan tarbiyah mulai
berkembang dan melebarkan
pengaruhnya pada fase kedua di tahun
1990-1998 yang merupakan fase di mana
gerakan tarbiyah sudah mulai terjun
langsung ke masyarakat, baik
masyarakat kampus maupun
masyarakat umum di sekitar kampus. Dalam masa ini begitu banyak aktivitasaktivtas sosial gerakan tarbiyah dengan menggunakan nama Yayasan yang didirikan oleh para aktivisnya. Fase ini semakin terlihat jelas saat Syaikh Tarbiyah Rahmat Abdullah (salah seorang "guru besar" gerakan tarbiyah) mendirikan Yayasan Iqra' di Bekasi. Pendirian yayasan tersebut semakin menjadikan kegiatan gerakan tarbiyah marak di tengah-tengah masyarakat. Begitu banyak kegiatan sosial yang diselenggarakan, dari mulai mengadakan TPA, majelis ta'lim, hingga pengobatan gratis dan pemberian santunan bagi masyarakat.

Aktivis gerakan tarbiyah di ITB juga turut mengikuti alur ini. Mereka kemudian mulai terjun langsung ke masyarakat, tidak hanya berkutat dengan aktivitasnya di GAMAIS, namun juga mengisi pengajian dan mengajar TPA di masjid-masjid sekitar tempat tinggalnya. Aktivitas ini dilakukan untuk mengubah paradigma masyarakat tentang gerakan dakwah atau gerakan islam secara umum yang semakin ternodai oleh tindakantindakan teror oknum sekaligus meraih dukungan masyarakat dari tindakan represif orde baru, terutama pasca tragedi Tanjung Priok, yang efeknya masih bisa dirasakan hingga awal tahun 1990-an. Namun demikian, memasuki tahun 1990, para aktivis dapat sedikit lega letika mendapat angin segar dengan pancabutan kebijakan NKK/BKK ${ }^{11}$ oleh Mendikbud Fuad Hasan yang kemudian menggantinya dengan SK No. 0457/U/1990 tentang Pedoman Umum Organisasi Kemahasiswaan (PUOK). PUOK mengakui keberadaan organisasi kemahasiswaan intra (didalam) kampus berupa Senat Kemahasiswaan Intra Kampus (SMPT) yang di dalamnya terdiri dari Senat Mahasiswa Fakultas (SMF) dan Unit Kegiatan Mahasiswa (UKM). Seiring dengan kebijakan baru ini, maka terjadi restrukturisasi aktivitas da'wah kampus secara kelembagaan (Culla, 1999: 89).

Menyambut angin segar ini, GAMAIS ITB kemudian turut mengambil momentum dengan menyatakan diri menjadi salah satu unit kegiatan kemahasiswaan di ITB pada bulan Maret 1991, di bawah koordinasi pembina unit yang tergabung dalam unit pendidikan. Sedangkan yang menjadi pembina Gamais ITB saat itu adalah Hermawan K. Dipojono dosen Teknik Fisika ITB yang juga menjabat sebagai Ketua Yayasan Salman ITB. Dalam fase ini, sikap ideologis aktivis dakwah kampus dari lebih melunak, mereka terlihat semakin cair dengan simbol-simbol nasionalisme NKRI. Hal ini nampaknya dilakukan untuk meredam sikap represif pemerintah

11 Terkait NKK/BKK dapat lihat, Supriyanto, Didik. 1998. Perlawanan Pers Mahasiswa: Protes Sepanjang NKK/BKK. Jakarta: Sinar Harapan. 
pasca kasus Tanjung Priok yang efeknya masih terasa hingga awal 1990-an. Selain itu, bisa jadi ini merupakan strategi Tarbiyah dalam meredam para aktivisnya dari tindakan-tindakan yang mendekati kekerasan.

Melunaknya sikap aktivis dakwah kampus ini semakin terlihat memasuki paruh kedua 1990-an, di mana mereka pun mulai semakin berbaur dengan masyarakat. Bahkan, para aktivis dakwah yang bergabung dalam organisasi-organisasi kampus pun mulai "menghormati" simbol-simbol nasionalisme NKRI. Dalam acara-acara kampus misalnya, mereka pun menyanyikan lagu Indonesia Raya pada awal acara untuk membukanya. Selain itu, simbol-simbol seperti burung garuda atau bendera merah putih pun sudah mewarnai atribut para aktivis dakwah. Bendera merah putih misalnya, mereka pasang sebagai bendera kebanggaan di lengan kanannya, namun di lengan kirinya biasanya ditempel bendera Palestina yang menunjukkan ikatan ideologis yang kuat antara mereka dengan Hamas di Palestina yang juga menganut pemikiran Ikhwan, walau tetap bersikap keras pada berbagai kesempatan yang khusus.

Setelah berkecimpung lama di dalam da'wah khashah (aktivitas perekrutan), maka saat dinilai cukup memiliki kekuatan, sekaligus sebagai implementasi dari Pedoman Dakwah Kampus 1994 adalah mulai ikut sertanya Aktivis Tarbiyah dengan LDK-nya dalam pemilihan kepemimpinan di Senat Universitas dan di beberapa Perguruan Tinggi, termasuk ITB. Ini merupakan langkah transformasi yang nyata setelah sekian lama berkonsentrasi di masjid, Gerakan Tarbiyah mulai melebarkan sayapnya menuju ke dunia politik. Hal ini pun tidak dapat dipungkiri merupakan pengaruh yang diberikan oleh Gerakan Ikhwan di Mesir.

Para Aktivis Dakwah ini mengirimkan wakilnya untuk menduduki posisi-posisi penting di kampus untuk memperkokoh kegiatan dakwahnya, seperti menjadi anggota bahkan ketua dari kabinet kemahasiswaannya. Di ITB, Presiden KM ITB berasal dari GAMAIS selama dua periode kepemimpinan di tahun 1998-2000. Perjalanan para aktivis dakwah kampus dalam dunia politik kampus merupakan sebuah sikap politik yang juga sangat berwarna Ikhwan. Tidak heran bila kemudian kita melihat sejak paruh kedua 1990-an begitu banyak aktivis dakwah yang membaurkan dirinya dalam aktivitas di luar aktivitas ke-Islaman. Namun, tujuan mereka tetap sama, yakni menjadikan setiap lingkungan kampus adalah lingkungan yang Islami. Selain itu, keterlibatan mereka dalam lembagalembaga formal kampus dapat mempermudah tujuan-tujuan yang telah mereka tetapkan. Caranya adalah dengan menggunakan kekuasaan yang mereka miliki untuk memasukkan sedikit demi sedikit ideology yang dianut kepada massa.

\section{Lahirnya Kammi sebagai Organisasi Mahasiswa dengan Latar Gerakan Tarbiyah}

Jika sebelumnya gerakan tarbiyah tidak mengidentifikasi secara langsung dan khusus dalam organisasi GAMAIS ITB, maka secara khusus KAMMI menjadi organisasi yang secara "legal formal" mengidentifikasi diri dengan latar gerakan tarbiyah. Para aktivis gerakan tarbiyah yang kemudian telah menyebar diberbagai kampus kemudian menginisiasi sebuah forum silaturahmi antar lembaga dakwah kampus untuk membentuk FSLDK (forum silaturahmi 
lembaga dakwah kampus). FSLDK kemudian mengadakan agenda pertemuan tahunan yang membahas berbagai sikap yang akan diambil oleh para aktivis lembaga dakwah kampus atas berbagai permasalahan di Indonesia.

Berkembangnya perhatian terhadap persoalan kebangsaan yang kemudian menjadi agenda besar yang dibahas pada FSLDK Nasional $X$ di Malang menjadi sebuah transformasi bagi Gerakan Da'wah Kampus, yang pada awalnya hanya berkecimpung pada wilayah keagamaan dan politik kampus saja menjadi sebuah gerakan politik (Kesatuan Aksi) berskala nasional. Diselenggarakan di tengah-tengah kondisi krisis ekonomi yang telah berjalan sekitar setahun serta hampir menjalar ke krisis politik, FSLDK Nasional X menjadi sebuah momentum awal dari terbentuknya sebuah organisasi yang cukup fenomenal. Di beberapa kampus negeri, pada saat itu, ramai digelar aksi-aksi pernyataan sikap mahasiswa, walaupun baru sebatas di dalam kampus. Berkembangnya perhatian terhadap persoalan kebangsaan yang kemudian menjadi agenda besar yang dibahas pada FSLDK Nasional X di Malang menjadi sebuah transformasi bagi Gerakan Da'wah Kampus, yang pada awalnya hanya berkecimpung pada wilayah keagamaan dan politik kampus saja menjadi sebuah gerakan politik (Kesatuan Aksi) berskala nasional. Diselenggarakan di tengahtengah kondisi krisis ekonomi yang telah berjalan sekitar setahun serta hampir menjalar ke krisis politik, FSLDK Nasional $\mathrm{X}$ menjadi sebuah gerbang awal terbentuknya sebuah organisasi fenomenal. Di beberapa kampus negeri, pada saat itu, ramai digelar aksi-aksi pernyataan sikap mahasiswa, walaupun baru sebatas di dalam kampus. ${ }^{12}$ Dalam pertemuan kali ini dua tokoh nasional diundang, yaitu Prof. Dr. Amin Rais dan Letjen Prabowo Subiyanto, namun keduanya berhalangan hadir. Diundangnya kedua tokoh itu berkaitan dengan sikap kritis Amin Rais terhadap pemerintahan Orde Baru dan dilanjutkan dengan dialog mahasiswa dengan ABRI - dalam hal ini pihak ABRI diwakili oleh Prabowo.

Dalam FSLDK Nasional $X$ terjadi perdebatan sengit terkait dengan bagaimana seharusnya sikap LDK terhadap krisis nasional yang terjadi. Putusan dari permasalahan tersebut akhirnya disepakati untuk dibahas oleh Tim Formatur yang beranggotakan delapan orang ${ }^{13}$ yang kemudian menghasilkan dua poin penting yaitu:

1. Membentuk sebuah wadah khusus bagi ADK baik di luar LDK ataupun FSLDK agar dapat merespon berbagai masalah yang dapat menimbulkan krisis nasional yang semakin parah.

2. Mendeklarasikan wadah baru tersebut setelah acara FSLDK selesai. Sehingga wadah tersebut bukan hasil keputusan FSLDK tetapi kesepakatan peserta (ADK).

Akhirnya setelah FSLDK Nasional X berakhir, terbentuklah sebuah wadah yang bernama Kesatuan Aksi Mahasiswa Muslim Indonesia (KAMMI) dengan Ketua Umum Fahri Hamzah dan Haryo Setyoko sebagai Sekretaris Umum. Wadah ini kemudian dideklarasikan pada hari Ahad (Minggu), 29 Maret 1998 pukul 13:30 di Aula UMM (Universitas Muhammadiyah Malang), beberapa saat setelah FSLDK secara resmi ditutup oleh Pembantu Rektor II UMM. Kemudian Nasional X

12 Dikutip dari lampiran laporan Panitia FSLDK 3 Ke delapan orang tersebut adalah Ananto Pratikno (UMM), Badaruddin (Unair), Edi Chandra (IPB), Faizal Sanusi (UI), Febri Nur Hidayat (ITB), Muhammad Arif Rahman (UGM), dan Suhendra (Undip). 
dilanjutkan

penandatanganan

"Deklarasi Malang" sebagai bentuk dukungan ADK terhadap berdirinya KAMMI. Namun, tercatat dari 200-an peserta FSLDK yang hadir, jumlah penandatangan adalah 133 orang, artinya ada sekitar 70-an peserta yang hadir pada saat itu yang tidak menandatangani "Deklarasi Malang". Adanya peserta yang tidak menandatangani deklarasi tersebut dapat difahami karena tidak seluruh peserta yang hadir merupakan aktivis Gerakan Tarbiyah.

Kehadiran KAMMI sebagai kekuatan besar pada gerakan 1998 menimbulkan banyak pertanyaan, terutama di kalangan media massa yang masih heran melihat sebuah fenomena yang langka terjadi di Indonesia. Sebagai sebuah organisasi yang baru 13 hari sejak kelahirannya sanggup menginisiasi sebuah gebrakan besar dalam dunia kemahasiswaan dengan menggelar agenda "Rapat Akbar Mahasiswa dan Rakyat Indonesia" di lapangan Masjid Al-Azhar, Jakarta pada tanggal 10 April 1998 yang kurang lebih dihadiri sekitar 20 ribu massa aksi. Termasuk di dalamnya adalah pada saat ratusan mahasiswa ITB juga turut serta di dalamnya, bergabung dalam barisan massa aksi. Bahkan tidak lama setelah deklarasi tersebut, pada bulan dan tahun yang sama, aktivis dakwah kampus ITB langsung mendeklarasikan berdirinya KAMMI ITB dengan Munawar dari Jurusan Teknik Elektronika sebagai ketuanya. ${ }^{14}$

Berdirinya KAMMI ITB adalah sebuah sikap politik yang tegas dalam merespon kondisi NKRI pada masa itu. Dengan adanya KAMMI ITB, aktivis dakwah kampus ITB memiliki wadah dalam menyatukan langkahnya untuk

${ }^{14}$ Wawancara dengan Vidia, aktivis KAMMI ITB, Desember 2009. memberikan kontribusi kepada apa yang mereka sebut sebagai ishlah ad daulah (memperbaiki negara). Dari pemahaman tersebut pula mereka kemudian turun ke jalan untuk menunjukkan sikap politiknya terhadap pemerintahan Orde Baru yang dianggap telah banyak memberikan kebijakan yang tidak pro rakyat. Walaupun bukan hanya KAMMI yang bersikap sama, namun KAMMI tetap memiliki ciri khas dalam menentukan sikap politik tersebut. Saat sebagian besar massa aksi menyerukan revolusi sebagai solusi bagi permasalahan ini, maka KAMMI telah menegaskan sikapnya yaitu ishlah ad daulah yang kemudian biasa disebut sebagai reformasi.

Istilah reformasi 1998 memang tidak kali pertama dimunculkan oleh KAMMI, namun KAMMI dengan massanya yang besar sanggup menyebarkan isu reformasi hingga mewarnai gerakan 1998 secara keseluruhan. Bahkan isu revolusi yang pada awalnya diusung oleh sebagian mahasiswa pun redup dengan sendirinya. Pada masa itu seluruh mahasiswa dan masyarakat bersatu untuk menggulirkan reformasi di Indonesia. Kehadiran KAMMI sebagai organisasi kemahasiswaan yang fenomenal ini menjadi berita hangat di beberapa media. Ciri khas yang disebutkan dalam beberapa uraian di atas adalah pemicunya. Aktivis lakilakinya terlihat santun dan hampir mayoritas dari mereka berjenggot tipis, sedangkan aktivis perempuannya lekat dengan jilbab lebar berwarna putih, sebuah fenomena yang (mungkin) belum pernah ada sebelumnya. Apalagi, dua pekan setelah dideklarasikan di Malang, KAMMI sanggup mengumpulkan kurang lebih 20000 massa yang datang dari beberapa kota 
di Indonesia, bahkan di antara mereka datang dari luar Jawa.

Fenomena tersebut tidak akan membuat kita terlalu heran jika kita mengikuti perjalanan tarbiyah dari masa ke masa. Pembinaan yang intensif, ideologisasi yang kuat, serta tradisi militer dimana kepatuhan menjadi harga mati telah mewarnai sikap para aktivis tarbiyah. Dua puluh ribu massa yang dikumpulkan oleh KAMMI di lapangan Al Azhar, Bekasi tidak seluruhnya mahasiswa. Mereka adalah masyarakat yang telah disatukan oleh pembinaan tarbiyah. Mahasiswa atau bukan, kaya atau miskin, muda atau tua, tidak menjadi persoalan, karena pada hakikatnya KAMMI pada saat itu telah menjadi kendaraan politik bagi para aktivis tarbiyah yang belum memiliki organisasi rersmi yang menaunginya. Pengaruh tarbiyah yang kental telah mewarnai sikap politik aktivis dakwah kampus. Dari mulai keterlibatan mereka dalam politik kampus, perubahan sikap ideologis pada akhir 1990-an, hingga deklarasi KAMMI tidak dapat dipungkiri merupakan hasil dari pengaruh tersebut. Dalam sikap tersebut begitu terlihat kentalnya warna Ikhwan, sehingga tidak mungkin dapat dipisahkan antara pembinaan yang dilakukan tarbiyah dengan sikap politik yang mereka keluarkan.

\section{Kesimpulan}

Dari uraian yang telah disampaikan sebelumnya dapat disimpulkan bahwa Gerakan Tarbiyah telah banyak memberikan pengaruh kepada kehidupan dakwah kampus di ITB khususnya, dan Indonesia secara umum. Aktivitas mahasiswa Muslim di ITB sebelum kehadiran tarbiyah tidak memiliki pola yang sistematis bila dibandingkan dengan pola gerakan tarbiyah. Selain itu, mereka tidak berhasil menyatukan sikap politik aktivis muslim pada saat itu. Sedangkan gerakan tarbiyah sanggup menyatukan gerak aktivis dakwah hingga dideklarasikannya KAMMI yang menjadi kendaraan politik bagi aktivis dakwah secara keseluruhan.

Gerakan tarbiyah yang merupakan bagian yang tidak terpisahkan dari $\mathrm{Al}$ Ikhwan Al Muslimun (Ikhwan) di Mesir berhasil membangun kekuatannya sejak sekitar 1983 dan mulai menjajaki dakwah kampus dua tahun setelahnya. Kehadiran tarbiyah dalam dunia kampus telah mengubah pola gerakan dakwah kampus menjadi sangat Ikhwan. Puncak dari pengaruh politis dari pembinaan gerakan tarbiyah di kampus adalah dengan dideklarasikannya KAMMI pada 29 Maret 1998, dimana KAMMI menjadi wadah politis bagi gerakan tarbiyah yang belum memiliki organisasi resmi pada saat itu. Sikap politik aktivis dakwah kampus lebih memilih untuk mengangkat isu reformasi daripada revolusi karena hal itulah yang diajarkan dalam pembinaan mereka. Ikhwan di Mesir tidak pernah mengenal revolusi, mereka cenderung ke arah reformasi dengan mengangkat isu ishlah ad daulah (memperbaiki negara). Hal inilah yang kemudian juga diangkat oleh para aktivis dakwah kampus ITB bersama KAMMI hingga bergulirnya peristiwa reformasi 1998 . 


\section{Daftar Referensi}

Asshidiqie, Jimly. (ed). 2002. Bang Imad:

Pemikiran dan Dakwahnya. Jakarta:

Gema Insani Press.

Azh-Zhawahiri, Ayman. 2008. Dari

Rahim Ikhwanul Muslimin ke

Pangkuan Al-Qaida (terj). Klaten:

Kafayeh.

Culla, Adi Suryadi.1999. Patah Tumbuh Hilang Berganti, Sketsa Pergolakan Mahasiswa dalam Politik dan Sejarah Indonesia 1908-1988. Jakarta: Raja Grafindo Press.

Imdadun, Muhammad. 2003. Transmisi Gerakan Revivalisme Islam Timur Tengah ke Indonesia (1980-2002): Studi Atas Gerakan Tarbiyah dan HTI).Yogyakarta. Makalah Seminar FSLDK.

Luth, Thohir. 1999. Mohammad Natsir Dakwah dan Pemikirannya. Jakarta: Gema Insani Press.

Machmudi, Yon. 2005. Partai Keadilan Sejahtera; Wajah Baru Islam Politik Indonesia.

Matta, Anis. 2006. Dari Gerakan Ke Negara; Sebuah Rekonstruksi Negara Madinah yang Dibangun dari Bahan Dasar Sebuah Gerakan. Jakarta: Fitrah Rabbani.

Sidiq, Mahfudz. 2003. KAMMI dan Pergulatan Reformasi (Kiprah Politik Aktivis Dakwah Kampus dalam Perjuangan Demokratisasi di Tengah Gelombang Krisis Nasional Multidimensi). Solo: Era Intermedia.

Supriyanto, Didik. 1998. Perlawanan Pers Mahasiswa: Protes Sepanjang NKK/BKK. Jakarta: Sinar Harapan. http://gamais.itb.ac.id/profil-gamais, diakses November 2009.

Laporan Panitia FSLDK Nasional X di Malang 1998.

NU Online

Wawancara dengan Vidia, aktivis KAMMI ITB, Desember 2009.

Wawancara dengan Rd Laili Al-Fadli, aktivis Tarbiyah di Unpad, November 2009.

Wawancara dengan Burhan, aktivis tarbiyah di ITB, Desember 2009. 